\title{
17 \\ Ilott v The Blue Cross (2017): Testing the Limits of Testamentary Freedom
}

\author{
BRIAN SLOAN*
}

\section{INTRODUCTION}

$\mathrm{W}$ HILE THE DEFAUlT position is that 'an Englishman still remains at liberty at his death to dispose of his own property in whatever way he pleases', ${ }^{1}$ the Inheritance (Provision for Family and Dependants) Act 1975 allows certain categories of claimant, including adult children, to seek discretionary provision from an estate in a manner that overrides a will and/or the intestacy rules. This chapter considers a case ultimately called Ilott $v$ The Blue Cross, ${ }^{2}$ the first case under the 1975 Act to reach the highest judicial level. The case involved an estranged but needy daughter who had been 'disinherited' by her mother in favour of various animal charities. As Lady Hale was eventually to put it, the case raised

some profound questions about the nature of family obligations, the relationship between family obligations and the state, and the relationship between the freedom of property owners to dispose of their property as they see fit and their duty to fulfil their family obligations. ${ }^{3}$

This chapter begins with a brief history of family provision legislation, including its application by courts in cases involving adult children before Ilott. It then examines the factual background of the Ilott case in some depth, making more use of an interview that the claimant gave to the Daily Mail than the author might ideally have liked. ${ }^{4}$ It then considers the long history of the litigation (caused in part by the traditional two-stage

\footnotetext{
*I am indebted to Penelope Reed QC and Hugh Cumber for making Judge Million's judgment available to me, and to the conference participants for their comments.

${ }^{1}$ Re Coventry (decd) [1980] Ch 461, 474 (Oliver J).

${ }^{2}$ Ilott v The Blue Cross [2017] UKSC 17, [2017] 2 WLR 979. At lower levels, the case was known variously as Ilott $v$ Mitson, $\mathrm{H} v$ Mitson or Hv J's Personal Representatives.

3 ibid [49].

${ }^{4} \mathrm{H}$ Weathers, 'All I Ever Wanted Was My Mum's Love: Daughter Left None of Her Mother's Estate Tells of the Bitter Family Rift behind Legal Case Which Saw Judges Overturn the Will' Daily Mail (London, 1 August 2015) www.dailymail.co.uk/news/article-3181900/All-wanted-mum-s-love-Daughter-left-none-mother-s-estatetells-bitter-family-rift-legal-case-saw-judges-overturn-will.html.
} 
approach to claims under the Act $)^{5}$ leading up to the Supreme Court's decision, including the first instance decision of District Judge Million that has not been published in full. ${ }^{6}$ The Supreme Court's judgments themselves are then analysed, including with reference to Ilott's early impact on academic writing and subsequent case law. By way of conclusion, the chapter makes the argument for Ilott as a 'landmark case'.

\section{A BRIEF HISTORY OF FAMILY PROVISION}

It has been seen that the predominant principle of English succession law is that of testamentary freedom. While Nield claims that the principle has existed since feudal times, ${ }^{7}$ Borkowski argues that 'testamentary freedom was severely limited for much of English legal history' and that testators were substantially unencumbered for only about a century. ${ }^{8}$ The testamentary freedom principle contrasts with the position in many civil law jurisdictions, where testamentary freedom is limited by compulsory portions of the estate being reserved for particular family members. ${ }^{9}$ The English Law Commission considered the introduction of compulsory portions for family members in $1971,{ }^{10}$ but subsequently rejected the idea. ${ }^{11}$ Family provision is therefore an important exception to the general rule of testamentary freedom.

The concept of family provision did not originate in England. The New Zealand Testator's Family Maintenance Act 1900 was the first statute in a common law jurisdiction to place testators under a legal duty to provide for their family and dependants. ${ }^{12}$ The Act was an attempt to prevent men from leaving their wives and children destitute by bequeathing their entire estate to persons outside the immediate family circle. It has been described as a 'highly significant landmark in the way in which common law jurisdictions dealt with succession to property on death', since its principles were adopted by all the Australian states and most of the Canadian provinces. ${ }^{13}$

The New Zealand statute was also influential in England, where considerable public and press support for reform to qualify testamentary freedom was claimed in the 1920 s. $^{14}$ The scope of family provision statutes in England and Wales, Australia and New Zealand has widened significantly compared to their original forms. ${ }^{15}$ An applicant under the original English Inheritance (Family Provision) Act 1938 had to be a spouse, an unmarried

\footnotetext{
${ }^{5}$ See, eg B Sloan, Borkowski's Law of Succession, 3rd edn (Oxford, Oxford University Press, 2017) 264 figure 9.1.

${ }^{6}$ Ilott v Mitson (HC, 7 August 2007).

${ }^{7} \mathrm{~S}$ Nield, “If You Look After Me, I Will Leave You My Estate”: The Enforcement of Testamentary Promises in England and New Zealand' (2000) 20 Legal Studies 86.

${ }^{8}$ A Borkowski, Textbook on Succession, 2nd edn (Oxford, Oxford University Press, 2002) 258.

${ }^{9} \mathrm{See}$, eg C Castelein, R Foqué and A Verbeke (eds), Imperative Inheritance Law in a Late-Modern Society (Antwerp, Intersentia, 2009); see also the chapters by Walter Pintens and Daniel Carr (chapters 18 and 19) in this volume.

${ }^{10}$ Law Commission, Family Property Law (Law Com No 42, 1971) pt 4.

${ }^{11}$ Law Commission, First Report on Family Property: A New Approach (Law Com No 52, 1973).

${ }^{12}$ Nield (n 7) 86 fn 6.

${ }^{13} \mathrm{~N}$ Peart and A Borkowski, 'Provision for Adult Children on Death - The Lesson from New Zealand' (2000) 12 Child \& Family Law Quarterly 333, 333.

${ }^{14}$ SM Cretney, Family Law in the Twentieth Century: A History (Oxford, Oxford University Press, 2003) 486.

${ }^{15}$ Peart and Borkowski (n 13) 333.
} 
or disabled daughter, or a son who was under 21 or disabled. ${ }^{16}$ Relief was limited to maintenance and subject to a maximum award of two-thirds of the net estate, the Act applied only to testate succession and there were restrictions on an adult child's ability to apply based on the proportion of the estate left to a spouse. Significantly, Probert has emphasised that 'the 1938 Act was the first legislative interference with freedom of testation as regards children', ${ }^{17}$ but both the provisions and the application of the Act were cautious. ${ }^{18}$

The 1938 Act was then the subject of piecemeal reforms. These included the extension of its application to intestacy, ${ }^{19}$ the inclusion of the former spouse who had not remarried as an eligible applicant ${ }^{20}$ and the removal of the restrictions on the proportion of the estate that a claim could exhaust. ${ }^{21}$

The Inheritance (Provision for Family and Dependants) Act 1975 removed the 'maintenance' restriction for spouses. Most significantly for present purposes, the 1975 Act extended the potential class of applicants to include all legal children of the deceased, in addition to those whom the deceased treated as a child of the family, and those who were factually dependent on the deceased irrespective of whether they had a familial relationship with her (cohabitants later being included through the Law Reform (Succession) Act 1995). Probert alleges that when the Law Commission recommended the removal of age limits for adult children, ${ }^{22}$ 'it provided no principled reasons for doing so and did not seem to envisage that many claims by adult children would be regarded as meritorious'. ${ }^{23}$ In his 2003 Family Law in the Twentieth Century: A History, however, Cretney opined that the distinction between the maintenance standard and the spousal standard 'might come to be seen as an anomaly'. 24

\section{A. Claims by Adult Children}

It is now necessary to outline the courts' approach to claims by adult children before Ilott. Under the 1975 Act, the court must ascertain whether the will and/or the intestacy rules 'make reasonable financial provision' 25 for the applicant's maintenance. ${ }^{26}$ The term 'maintenance', in turn, has been defined as in Re Dennis as encompassing 'payments which, directly or indirectly, enable the applicant in the future to discharge the cost of his daily living at whatever standard of living is appropriate to him' ${ }^{27}$ If the court concludes that reasonable financial provision has not been made, it must then decide which of its powers to exercise in order to remedy that insufficiency. ${ }^{28}$ Section 3 of the Act contains a list of factors to which the court should have regard in making its determinations,

\footnotetext{
${ }^{16}$ For a detailed discussion of the 1938 Act, see Cretney (n 14) 485-98.

${ }^{17}$ R Probert, 'Family and Other Animals' (2017) 133 LQR 550, 553 (original emphasis).

${ }^{18}$ Cretney (n 14) 496-97.

${ }^{19}$ Intestates' Estates Act 1952.

${ }^{20}$ Matrimonial Causes (Property and Maintenance) Act 1958.

${ }^{21}$ Family Provision Act 1966.

${ }^{22}$ Law Commission, Second Report on Family Property: Family Provision on Death (Law Com No 61, 1974) [79].

${ }^{23}$ Probert (n 17) 553.

${ }^{24}$ Cretney (n 14) 511.

${ }^{25}$ Inheritance (Provision for Family and Dependants) Act 1975 (hereafter 1975 Act), s 1(1).

${ }^{26} 1975$ Act, s 1(2)(b). Spouses and civil partners are not subject to this limitation: s 1(2)(a-aa).

${ }^{27}$ Re Dennis (decd) [1981] 2 All ER 140, 145 (Browne-Wilkinson J).

${ }^{28} 1975$ Act, s 2 .
} 
some of which apply to all applicants ${ }^{29}$ and some of which are aimed specifically at claims by children of the deceased. ${ }^{30}$

The focus of the award of relief is very much on the future needs of the applicant considered at the date of the hearing, due to the 'maintenance' limitation. ${ }^{31}$ For example, the Act specifies 'the manner in which the applicant was being or in which he might expect to be educated or trained' in applications by adult children, a distinctly forwardlooking and potentially limiting factor. ${ }^{32}$ Indeed, although the award is not necessarily limited to providing 'bare necessities', ${ }^{33}$ it was suggested by Peart and Borkowski that the English judiciary adopted a 'parsimonious' approach to claims by adult children. ${ }^{34}$ This is encapsulated in Browne-Wilkinson J's remark in Re Dennis that:

A person who is physically capable of earning his own living faces a difficult task in getting provision made for him, because the court is inclined to ask: 'Why should anybody else make provision for you if you are capable of maintaining yourself?"35

It seemed that a claim by an adult child in employment and/or with future earning capacity was unlikely to succeed in England unless the applicant could show that the deceased owed a moral obligation to him, or that some other special circumstances justify the order ${ }^{36}$ although the size of the estate was a pertinent consideration. ${ }^{37}$ In Re Coventry, ${ }^{38}$ 'regarded as the leading authority', ${ }^{39}$ no provision was made for an adult son who had lived with his now-deceased father for a significant period and was earning only modestly, in circumstances where his needy mother would have been prejudiced by an award to him. It was suggested that a moral obligation could be generated by an applicant's forgoing of an adequate living to look after a disabled parent. However, neither the first instance judge nor the Court of Appeal could find sufficient evidence of such a sacrifice on the facts.

The tendency to emphasise a need to show moral obligations owed by the deceased in the English case law involving adult children ${ }^{40}$ has been criticised as a value-laden relic of earlier legislation. ${ }^{41}$ In Espinosa $v$ Bourke, Butler-Sloss LJ denied that the Court of Appeal had placed a 'gloss' on the language of the present legislation, ${ }^{42}$ under which

\footnotetext{
${ }^{29} 1975$ Act, s 3(1).

${ }^{30} 1975$ Act, s 3(3).

${ }^{31}$ See generally G Miller, 'Provision for Adult Children under the Inheritance (Provision for Family and Dependants) Act 1975' [1995] Conveyancer \& Property Lawyer 22.

321975 Act, s 3(3).

${ }^{33}$ N Lowe and G Douglas, Bromley's Family Law, 11th edn (Oxford, Oxford University Press, 2015) 983.

${ }^{34}$ Peart and Borkowski (n 13) 333.

${ }^{35}$ Re Dennis (n 27) 145.

${ }^{36}$ Re Hancock (decd) [1998] 2 FLR 346, 351. The idea of moral duty receives some attention in Nicola Peart's contribution (chapter 12) to this volume.

${ }^{37}$ Myers $v$ Myers [2004] EWHC 1944 (Fam), [2005] WTLR 851.

${ }^{38}$ Re Coventry (n 1).

${ }^{39}$ H Conway, 'Do Parents Always Know Best? Posthumous Provision and Adult Children' in W Barr (ed), Modern Studies in Property Law (Oxford, Hart Publishing, 2015) 118.

${ }^{40}$ This has been caused mainly by the 'misinterpretation' of Re Coventry, which prevailed for some time: A Borkowski, 'Moral Obligation and Family Provision: Re Hancock (Deceased) and Espinosa v Bourke' (1999) 11 Child \& Family Law Quarterly 305.

${ }^{41} \mathrm{~J}$ Wilson and R Bailey-Harris, 'Family Provision: The Adult Child and Moral Obligation' (2005) 35 Family Law 555 .

${ }^{42}$ Espinosa v Bourke [1999] 1 FLR 747, 755.
} 
the court is directed to have regard, inter alia, to 'any obligations and responsibilities which the deceased had towards any applicant'. ${ }^{43}$ All of the judges in that case expressed misgivings about the use of the word 'moral', emphasising that it was intended simply to avoid restricting relevant obligations to legal ones. In Re Hancock, moreover, it had previously been confirmed that a moral obligation was not a precondition of a successful application. ${ }^{44}$ The concept of a moral obligation remained in evidence, however, and Borkowski noted that the courts were often reluctant to clarify its meaning. ${ }^{45}$ There is some suggestion that care could be a relevant 'moral obligation', even though it is not necessary to demonstrate one. In Re Jennings, Henry LJ considered a hypothetical scenario in which an adult child gave up a university place 'to nurse the deceased through his long last illness'. ${ }^{46}$ Henry LJ suggested that there would be a 'clear' moral obligation on the deceased to enable the applicant to take up that place. ${ }^{47}$

In Espinosa $v$ Bourke, it was accepted that the applicant was owed a moral obligation by her deceased father because of the care that she provided for him (as well as because of a promise that he would leave certain property to her). ${ }^{48}$ The first instance judge found that any obligation had been discharged by the deceased during his life through direct transfers and benefits in kind. On appeal, however, it was held that the judge had focused too heavily on the obligation question at the expense of considering the applicant's financial position. The Court of Appeal concentrated instead on the applicant's lack of earning capacity and the promise of provision that the father had made in allowing the applicant's appeal and making an order. The first instance judge was influenced by the fact that the applicant's commitment to her father dwindled, implying that a failure to care for a deceased parent may have a negative effect on a claim under the Act. Although the Court of Appeal made an order on the basis of her need and the promise made to her, Butler-Sloss LJ admitted that the daughter's eventual neglect of her father could have counted against any obligation owed to her because of her care. ${ }^{49}$ Provision was nevertheless made despite the neglect and the fact that she found herself in necessitous circumstances due at least in part to a lifestyle of which the deceased clearly disapproved.

If disapproval was not fatal to claims under the Act, nor was estrangement. In Gold $v$ Curtis, provision was made for an estranged daughter with mental health issues. ${ }^{50} \mathrm{~A}$ need for maintenance was key, however: on the facts of Re Jennings, no obligation was found on the part of the deceased father in spite of the fact that he had failed to maintain the applicant (a 45-year-old successful businessman at the time of the father's death) during his minority.

As for the relationship between family provision and state benefits, courts were generally reluctant to attach a great deal of significance to the availability of state support for a family provision applicant, particularly in cases involving large estates. ${ }^{51}$ In summarising

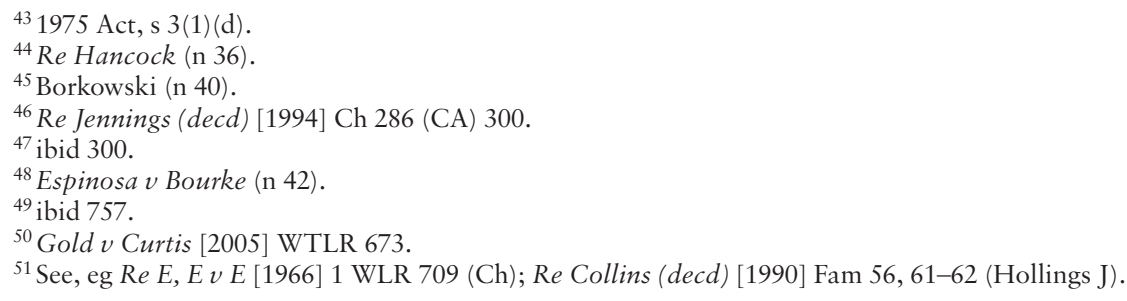


the courts' approach to claims by adult children before Ilott, Conway wrote that '[s]ince Re Coventry, much judicial time and effort has been expended on trying to formulate a workable and coherent set of universal principles to supplement the statutory framework for determining family provision claims by independent adult children', but '[ $t$ ] he extent to which courts have succeeded in this objective is questionable'. ${ }^{22}$ She was also of the view that 'there are no discernible trends in the value of any award relative to the value of the deceased's estate, and few attempts to rationalise the sum given to the claimant by the court'. ${ }^{53}$

\section{THE FACTUAL BACKGROUND TO THE ILOTT CASE}

Melita Jackson was born in $1934 .{ }^{54}$ At 21 , she married Thomas, who was killed in an industrial accident at the BBC (falling 600 feet from a broadcasting mast while not wearing a helmet $)^{55}$ just four years later while Melita was pregnant with their daughter, Heather. In 1978, at the age of 17, Heather left home to go and live with her boyfriend Nick Ilott at his parents' home. Heather did so without telling Melita, who disapproved of Nick because she thought that he would not make much of his life (apparently because of his parents' circumstances) ${ }^{56}$ and that Heather was thus wasting her future. Melita was shocked and called the police. Heather was found at the Ilotts' home and refused to return to Melita.

Heather married Nick in 1983, again without telling Melita. She gave birth to A the following year, and set up home with Nick and A in a cottage in Ware ${ }^{57}$ in Hertfordshire rented from a housing association. She subsequently gave birth to B in 1987, L in 1988, $\mathrm{M}$ in 1991 and $\mathrm{E}$ in 1996. At the time of Judge Million's decision, she and Nick lived in the same Hertfordshire house with the youngest four children. She had not done any paid work since A's birth, she and Nick having decided that she would be a stay-at-home mother. Having worked as a delivery driver, he developed a back problem and worked part-time as a non-speaking supporting actor in television and films at the time of the judgment. By the time of the 2014 High Court judgment, evidence (by way of anonymous letter) had emerged that Nick was offering 'spiritualist services', but he claimed not to profit from these and Parker J discounted the evidence. ${ }^{58}$

At the time of Judge Million's judgment, A was a care worker living away from home, B was living at home and working as a plumber's apprentice, and the younger three lived at home and were either in or seeking education. Heather and Nick's joint net annual income was put at around $£ 15,000$, over half of which came from tax credits, plus $£ 5,000$ in housing and council tax benefits. They were left with just over $£ 14,000$ after payment of rent and council tax, and 'lived modestly and within their means' ${ }^{59}$

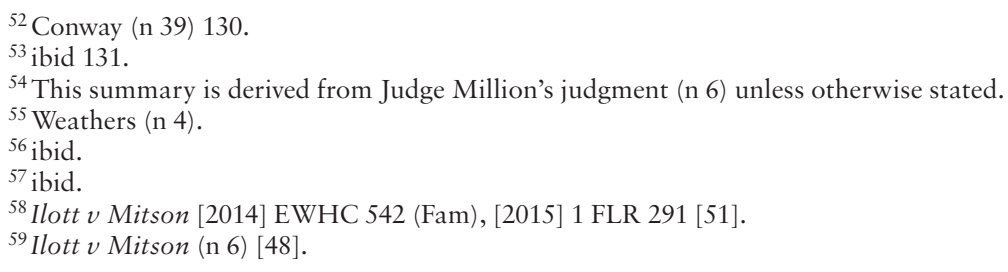


Heather and Melita attempted to reconcile over the years: first when Heather was pregnant with A until a few months after his birth, then between April and June 1994, and finally for six months between 1999 and 2000. Significantly, Melita made a will in 1984 (while she and Heather were on speaking terms) that excluded Heather. The ending of each short-lived reconciliation was characterised by bitterness and aggression.

In 2002, Melita made her last will. In it, she left a $£ 5,000$ legacy to the BBC Benevolent Fund $^{60}$ (which had apparently provided for her following Thomas's death ${ }^{61}$ and divided the residue between the Blue Cross, the Royal Society for the Protection of Birds and the Royal Society for the Prevention of Cruelty to Animals. She wrote a letter of wishes explaining her decision to exclude Heather from the will, referring to the 1978 separation and claiming that she had seen her daughter only twice since then, that Heather had made no effort to reconcile with her and that Heather had used 'lies and deceit'. Judge Million found that the letter contained 'many inaccuracies' and was 'unfairly critical' of Heather. ${ }^{62} \mathrm{He}$ also found that

the overwhelming and longstanding reason why Mrs Jackson made no provision to her daughter was that she had left the home of her mother at the age of $17 \ldots$ to go to and remain with a man of whom the mother disapproved. ${ }^{63}$

While Melita had asked for an apology and received one in both oral and written form, Judge Million was of the view that 'the only apology which would have satisfied Mrs Jackson is one in which Mrs Ilott in effect rejected her own husband'. ${ }^{64}$

Melita had no particular connection with the animal charities between which she had divided her residuary estate, or animal welfare or birdlife more generally, with Heather recalling having only a single pet dog while she was growing up and suspecting that Melita had benefited the charities 'to hurt [Heather] even more'. ${ }^{65}$

Melita died in 2004 at the age of 70, having lived alone since the death of her longterm companion in 1996. Her body was not discovered until several days after her death. Judge Million described her as 'lonely, isolated and reclusive' by the end of her life, ${ }^{66}$ and the only mourners at her funeral were Heather, Nick, their five children, Melita's solicitor and one other person. Melita's net estate was valued at $£ 486,000$ in cash or liquid assets, described as 'significant $\ldots$ but not unusually large'. ${ }^{67}$

Heather claimed that at least some of the money represented by Melita's estate was inherited by Melita following Thomas's death, notwithstanding the fact that Melita claimed to have been left 'penniless'. ${ }^{68}$ Heather described her motivation in bringing the 1975 Act claim as not being about the money per se, but about 'the principle' of accomplishing what ' $\left[\right.$ her] late father would have wanted for the child he never lived to see'. ${ }^{69}$

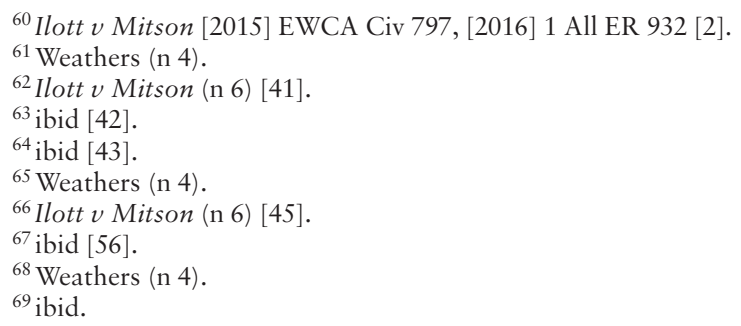


The charities, meanwhile, accepted that their resources and needs were 'irrelevant', ${ }^{70}$ a concession that was to be significant as the case proceeded through the courts.

\section{THE ROAD TO THE SUPREME COURT}

\section{A. Judge Million's Decision}

Judge Million granted Heather's application and awarded her $£ 50,000$ out of the estate. Judge Million described Melita as owing Heather 'the ordinary family obligations towards her only child who was an independent adult' ${ }^{71}$ albeit that Melita had 'gone out of her way' to tell Heather that 'she felt no responsibility towards her as a daughter'. ${ }^{72}$ The judge rejected the suggestion that Heather could not complain about a lack of provision because she had 'thrown her lot' in with a man against her mother's wishes. On his analysis, "[a] daughter is entitled (indeed would be expected) to make a life with a partner of her choice and a family of her own', and 'would reasonably hope that a parent would accept such a choice and not blame her for it'. ${ }^{73}$ While he accepted that Heather and Nick 'contributed to some of the later difficulties in effecting a sustained reconciliation', ${ }^{74}$ he described Melita's reasoning and decision as "capricious and unfair" ${ }^{75}$ and 'harsh and unreasonable' ${ }^{76}$

Following his application of the statutory factors in light of Re Coventry and Espinosa $v$ Bourke, Judge Million held that an 'unreasonable result' had been produced by the will in that no provision was made in circumstances of 'some financial need'. ${ }^{77}$ Judge Million accepted that Heather had 'some possibility in the future of obtaining part-time work', but was conscious that she lived in an 'isolated' village and had no driving licence. ${ }^{78}$ At the same time, he was clear that Heather and Nick had no expectation of provision, which did not mean 'that the result is a reasonable one in the straightened [sic] financial circumstances of the family', but did mean 'that any provision now must be limited' ${ }^{79}$

On the second stage, concerning what provision should be made for Heather, all parties were agreed that any award should take the form of a capitalised sum, albeit that Judge Million was conscious that such a sum 'must be based on income need' ${ }^{80}$ In response to inevitably conflicting submissions on the size, including some that would have involved an award exceeding the size of the estate and had not adequately taken account of the effect on benefits, Judge Million undertook a more 'rough and ready' approach. ${ }^{81}$ Having taken account of the tax credits position, he regarded around $£ 4,000$

\footnotetext{
${ }^{70}$ Ilott v Mitson (n 6) [50].

71 ibid [51].

72 ibid [55].

73 ibid [58].

74 ibid [59].

${ }^{75}$ ibid.

${ }^{76}$ ibid [60].

77 ibid [67].

${ }^{78}$ ibid [48].

${ }^{79}$ ibid [67].

${ }^{80}$ ibid [68].

81 ibid [75].
} 
as an 'indicated amount of maintenance that the government accepts as being needed currently to provide [Heather] with a reasonable, but basic, standard of living'. ${ }^{82}$ With reference to the Duxbury tables used on divorce, ${ }^{83}$ he then deduced that the amount needed to produce such an income would be around $£ 69,000$, and reduced it in light of the expectation that Heather should find some work to produce a sum of $£ 50,000$.

It is easy to see why the judge's conclusion and its relationship with Heather's benefits position was to become such an issue in subsequent proceedings. It is not immediately clear why he took account of the approximately $£ 4,000$ figure. On its own, this might suggest that he was intending to replace the relevant portion of Heather's income, yet it seems clear that he was intending not to affect her entitlements. That, however, leaves the question why he thought she should have double the government's 'indicated amount', though it may be that his objective was to ensure that the Act independently provided an accepted standard of living which the state could supplement, but without the need for the court to take into account the supplement.

\section{B. The High Court in 2009}

Heather appealed as to quantum (ie the second stage), prompting the charities to crossappeal the finding that Melita's will had not made reasonable financial provision for her (the first stage). ${ }^{84}$ The charities successfully convinced Eleanor King J that Judge Million had erred in law by asking the wrong question, because he had focused on whether Melita had acted unreasonably (which was the explicit judicial approach under the $1938 \mathrm{Act}^{85}$ but not the 1975 Act) rather than whether the result produced by the will was objectively unreasonable. Heather and Nick had not expected any provision, and Heather had apparently accepted that situation. Moreover, 'the single most relevant fact which determined the deceased's decision to exclude the daughter from her will was a breach of the most profound and enduring nature ... from a time when the daughter was only 17 years old'. ${ }^{86}$ Heather's circumstances were due to 'lifestyle choices', and there was no basis on which the family could look forward to a windfall. ${ }^{87} \mathrm{~A}$ 'weighty factor' was required before an applicant with earning capacity could succeed and there was nothing in the ordinary obligations of a mother or the conduct of the parties that could constitute one. ${ }^{88}$

Eleanor King J held that in any event, Judge Million had erred in his balancing of the section 3 factors. He had overemphasised subjective reasons, failed to take a holistic approach to the factors and come 'perilously close to allowing necessitous circumstances to be determinative'. ${ }^{89}$ In her view, 'the court was left with a filial relationship and necessitous circumstances with nothing more of sufficient cogency to drive a court to conclude

\footnotetext{
${ }^{82}$ ibid [79].

${ }^{83}$ Family Law Bar Association, At A Glance 2007-08: Essential Tables for Financial Remedies (London, Family Law Bar Association) Table 20.

${ }^{84} \mathrm{H} v$ Mitson [2009] EWHC 3114 (Fam), [2010] 1 FLR 1613.

${ }^{85}$ Cretney (n 14) 497.

${ }^{86} \mathrm{H} v$ Mitson (n 84) [61].

${ }^{87}$ ibid.

${ }^{88}$ ibid.

${ }^{89}$ ibid [64].
} 
that, in all the circumstances of the case, no provision for the daughter was unreasonable provision'.$^{90}$ The charities' cross-appeal was allowed and Heather's appeal dismissed (without her submissions on quantum having been heard).

\section{The Court of Appeal in 2011}

Heather successfully appealed against Eleanor King J's decision. ${ }^{91}$ In the Court of Appeal, Sir Nicholas Wall asserted that he did not base his decision 'on the ground that a claim under the Act can properly be used to relieve the State of the obligation to support an applicant'. ${ }^{92}$ Similarly, on Arden LJ's analysis, '[ $t$ ]he fact that the State makes provision for financial hardship does not mean that it is reasonable for a testatrix to make no provision for an adult child'. ${ }^{93}$

Sir Nicholas Wall held that he could not sustain Eleanor King J's criticism of the District Judge because Judge Million had explicitly asked whether the result was unreasonable. Black LJ agreed, although she acknowledged that he had also evaluated Melita's conduct earlier in his judgment. Moreover, Judge Million was not required to " "balance" the section 3 factors or to explain why the combination of factors under section 3 led him to the conclusion that no provision was unreasonable'. ${ }^{94}$

Sir Nicholas Wall directed that 'the appellant's appeal against the quantum of the district judge's decision be heard by a judge other than Eleanor King J' ${ }^{95}$ The Supreme Court then refused permission to appeal the Court of Appeal's conclusion. ${ }^{96}$ Given the subsequent emphasis on testamentary freedom and the suggestion that Heather was somewhat fortunate in the Supreme Court's eventual judgment on quantum, one can perhaps detect a tinge of regret that permission to appeal on the first stage was refused.

Writing after the 2011 Court of Appeal decision, Conway opined that

There is little doubt that the $\ldots$ decision strengthens the idea of adult children being able to make a successful financial provision claim despite not having been financially dependent on their parent (even for many years), and raises questions as to what steps a testator can actually take to disinherit an adult child. ${ }^{97}$

She accused the court of 'merely pa[ying] lip service to the notion of testamentary freedom', ${ }^{98}$ an issue that would rear its head again when the Court of Appeal was next to give judgment in the case. That said, it must also be borne in mind that, throughout the life of the 1975 Act, it has been a calculated risk to 'disinherit' children who might need maintenance in the future, and that the deceased's views and intentions have

${ }^{90}$ ibid [67].

${ }^{91}$ Ilott v Mitson [2011] EWCA Civ 346, [2012] 2 FLR 170.

92 ibid [14].

${ }^{93}$ ibid [75].

${ }^{94}$ ibid [52].

95 ibid $[60]$.

${ }^{96}$ Supreme Court, 'Applications for Permission to Appeal Results June 2011' www.supremecourt.uk/docs/ PTA-1106.pdf.

${ }^{97}$ Conway (n 39) 126.

98 ibid. 
always been somewhat relevant to, but obviously not conclusive of, the appropriate level of provision. Ilott, moreover, was by no means the most dramatic case in which provision has been made for an adult child. In Re Land (decd), ${ }^{99}$ for example, an adult son successfully claimed provision from his mother's estate notwithstanding his conviction for her gross negligent manslaughter and the resulting application of the forfeiture rule ${ }^{100}$ to his share under her will (albeit that the case can be explained in part by the court's inability to modify the rule's application due to delay). Moreover, it has been seen that neither disapproval of lifestyle ${ }^{101}$ nor estrangement ${ }^{102}$ has inevitably prevented awards in previous cases.

\section{The High Court in 2014}

Despite the Court of Appeal's hope that a further hearing could in fact be avoided, Parker J gave judgment upholding Judge Million's conclusion in 2014. ${ }^{103}$ Parker J rejected the argument that the sum paid to Melita on Thomas's death should be paid to Heather because it derived from Thomas, since there was 'no evidence to suggest that this sum was anything other than a payment to the deceased as widow'. ${ }^{104}$ Judge Million's award was 'intended to provide the claimant with a windfall for her to spend as she liked in improving her circumstances'. ${ }^{105}$ He had not been given the material with which to ascertain the precise effect on benefits, but Parker J had not been given it even then. It could not be said that the judge was wrong in taking the view that notwithstanding that the claimant and her husband and family lived in straightened circumstances, the fact they had done so for so many years did not justify an award which improved their circumstances', ${ }^{106}$ which appears to accept that the award had no substantive effect. Nevertheless, Parker J opined that it could not be correct that 'because there will be no benefit to the claimant unless her housing need is met, the award must achieve that result', since that would render 'meaningless' Judge Million's conclusion that the lack of expectation tempered the award. ${ }^{107}$

\section{E. The Court of Appeal in 2015}

Heather then appealed Parker J's conclusion on quantum. Giving judgment on the case for the second time in the Court of Appeal, Arden LJ identified two 'fundamental errors' in Judge Million's approach. ${ }^{108}$ The first was the fact that the judge stated that

\footnotetext{
${ }^{99}$ Re Land (decd) [2006] EWHC 2069 (Ch), [2007] 1 WLR 1009.

${ }^{100}$ Forfeiture Act 1982, s 1.

${ }^{101}$ Espinosa v Bourke (n 42).

102 Gold v Curtis (n 50).

${ }^{103}$ Ilott v Mitson (n 58).

104 ibid [41].

105 ibid [51].

106 ibid [52].

107 ibid.

${ }^{108}$ Ilott v Mitson (n 60) [35].
} 
the award should be 'limited' because of the applicant's lack of expectation of provision and her ability to live within her current means, but wrongly omitted to explain 'what the award might otherwise have been and to what extent it was limited by the matters in question'. ${ }^{109}$ The second error was the judge's failure to verify what effect his award would have on the applicant's entitlement to state benefits, simply assuming that a large capital payment (even including the one he made) would disentitle the family to most, if not all, of their benefits.

In light of those perceived errors, the Court of Appeal proceeded to exercise the discretion afresh, considering the section 3 factors in relation to the facts as they stood at the time of its own judgment. In doing so, Arden LJ noted that the charities did not have any relevant resources or needs, and that anything they received from the estate was a windfall. In addition, they were not held to have any expectation of such a benefit, since Melita had had no involvement with them during her lifetime.

While Arden LJ accepted that Heather was an adult child living independently - a relevant factor meaning 'at a minimum' that the court was 'not concerned to provide her with an income that would fully support her needs' 110 - Arden LJ also agreed that Heather's current standard of living was not conclusive regarding the appropriate level of maintenance, and reaffirmed that an adult child did not need to show a moral obligation or other special circumstance in order to succeed. The absence of an expectation of inheritance on her part was not to be given 'much weight', since Arden LJ upheld Judge Million's finding that Heather 'was deprived of any expectation primarily because Melita had acted in an unreasonable, capricious and harsh way towards her only child'. ${ }^{111}$

In response to conflicting submissions from Heather and the charities on the weight that should be attached to Melita's testamentary intentions, Arden LJ concluded that Parliament had 'entrusted the courts with the power to ensure, in the case of even an adult child, that reasonable financial provision is made for maintenance only', and that this limitation itself gave appropriate weight to testamentary freedom at least in cases where the other claimants on the estate have no demonstrated need or expectation. ${ }^{12}$ She later accepted, however, the need to balance claims on the estate 'fairly', ${ }^{113}$ albeit surprisingly suggesting that the charities were 'not prejudiced' by a higher award. ${ }^{114}$ Arden LJ refused to hold that the estrangement should eliminate or substantially diminish an appropriate award. There was no suggestion that Heather had wanted to be estranged from Melita, Heather's disapproved lifestyle choices had nevertheless allowed her to become a successful mother and homemaker, and fault for the estrangement was difficult to apportion and might even have been absent.

In evaluating Heather's needs and resources, Arden LJ noted the absence of any savings and her limited income and earning capacity, the latter being something that

\footnotetext{
109 ibid.

110 ibid [49].

111 ibid [51](iii).

112 ibid [51](v).

113 ibid [60].

114 ibid [61].
} 
could only have diminished since Judge Million's original decision. Even including her state benefits, it was held that Heather's resources were 'at such a basic level that they outweigh the importance that would normally be attached to the fact that [she] is an adult child who had been living independently for so many years'. ${ }^{115}$ Having earlier recognised that the size of the estate did not 'impinge' on the award sought, ${ }^{116}$ and aiming to preserve the family's state benefits, Arden LJ ultimately concluded that Heather should receive $£ 143,000$ to enable her to purchase the housing association property, in addition to the reasonable costs of the purchase. Heather was also given an option to claim up to $£ 20,000$ as a capital sum from the estate, in order to provide 'a very small additional income to supplement her state benefits'. ${ }^{117}$

The Court of Appeal's judgment caused a stir in some quarters, not least to the Comment Editor of the Daily Telegraph, who wrote the day after the judgment that '[a]ll of a sudden, the judges are trampling on the deepest and darkest fabric of family life'. ${ }^{118}$ Moreover, despite its interview with Heather considered earlier in this chapter (which may have saved her from some abuse), the Daily Mail also published a comment piece by Max Hastings, under the headline 'Who are judges to tell us who we can leave our money to in our wills!', in which he acknowledged the 'compassion' of the decision but intemperately attacked it as 'as yet another example of the mounting alienation between [lawyers] and the rest of humanity'. ${ }^{119}$ Both the Daily Telegraph and Daily Mail columns conveniently omitted to mention the fact that, while one can legitimately query its exercise on particular facts, the judiciary's power was expressly conferred by Parliament via the 1975 Act. While it might reasonably be construed as an attack on the core principle of testamentary freedom, particularly if it limits the extent to which testamentary intentions should be specifically evaluated against reasonable financial provision, the 2015 decision stopped very far short of introducing the kind of 'forced heirship' associated with civil law jurisdictions.

While Ilott at this stage did not therefore represent a sea change in the law, the portion of the estate awarded to Heather was considerable (albeit that her need was relatively high) and the judgment provided pause for thought to solicitors advising clients wishing to exclude adult children from their wills, particularly in favour of non-natural persons such as charities. Whatever the complaints, the Law Commission's most recent report to consider the 1975 Act recommended no change in the approach to adult children and appeared to assume that any reform would be in the direction of facilitating increased rather than decreased provision for adult children in any event. ${ }^{120}$ The charities, meanwhile, appealed to the Supreme Court.

\footnotetext{
115 ibid [57].

116 ibid [50].

117 ibid [63].

${ }^{118} \mathrm{H}$ de Quetteville, 'Belt Up Judges, I'll Disinherit the Kids if I Want' The Telegraph (London, 28 July 2015) www.telegraph.co.uk/lifestyle/11768612/Belt-up-judges-Ill-disinherit-the-kids-if-I-want.html.

${ }^{119}$ M Hastings, 'Who Are Judges to Tell Us Who We Can Leave Our Money to in Our Wills!' Daily Mail (London, 29 July 2015) www.dailymail.co.uk/debate/article-3178080/MAX-HASTINGS-judges-tell-leavemoney-wills.html.

${ }^{120}$ Law Commission, Intestacy and Family Provision Claims on Death (Law Com No 331, 2011) [6.2]-[6.26].
} 


\section{THE SUPREME COURT'S DECISION}

\section{A. Lord Hughes's Main Judgment}

The Supreme Court unanimously allowed the charities' appeal, restoring Judge Million's original $£ 50,000$ order. Lord Hughes (with whose main judgment all six other Justices agreed) accepted that '[s]ome of the factors inevitably dealt with in [the Supreme Court's] judgment may apply also to types of case other than those of adult children living separately from the deceased', but he was clear that 'there is no occasion for this court to attempt to meet every difficulty to which claims for family provision may give rise'. ${ }^{121}$

Lord Hughes reasserted the centrality of testamentary freedom in English law. $\mathrm{He}$ emphasised the importance of the 1975 Act's limitation to 'reasonable financial provision' for maintenance for non-spouse/civil partner applicants, reflecting what was described as a 'deliberate legislative decision' that was 'important'. ${ }^{122}$ He also held that a need for maintenance was a necessary but not sufficient condition for a successful claim.

The Supreme Court considered the maintenance standard at some length. Lord Hughes approved previous case law in holding that maintenance could not 'extend to any or every thing which it would be desirable for the claimant to have', ${ }^{123}$ but was not limited to 'subsistence' either. ${ }^{124}$ Needs would not necessarily be the measure of what is provided by the court if it has been concluded that reasonable financial provision has not been made by the will and/or the intestacy rules: the claims of others, and importantly the relationship between the claimant and the deceased, could justifiably limit the size of the award.

Lord Hughes also confirmed that the focus of the correct test under the 1975 Act is not on the behaviour of the testatrix, but opined the reasonableness of her decision (not always easily distinguishable from that of a result) may still be a significant consideration. This is also true of the extent of any 'moral claim', which will often be at the centre of the decision under the 1975 Act, particularly in claims by adult children capable of living independently, even if that is not a 'sine qua non'. ${ }^{125}$ While Lord Hughes did not reject the traditional two-stage approach to the Act, he did say that in many cases 'exactly the same conclusions will both answer the question whether reasonable financial provision has been made for the claimant and identify what that financial provision should be'. ${ }^{126}$

The Supreme Court unanimously held that Judge Million had not made either error alleged by the Court of Appeal. On the first (that he did not explain what the award would have been had it not been 'limited'), the Act required 'a single assessment ... of what reasonable financial provision should be made in all the circumstances of the case'. ${ }^{127}$ It did not require the judge 'to fix some hypothetical standard of reasonable

\footnotetext{
${ }^{121}$ Ilott v The Blue Cross (n 2) [3].

122 ibid [13].

123 ibid [14].

${ }^{124}$ ibid [15]

125 ibid [20].

${ }^{126}$ ibid [24].

127 ibid [34].
} 
provision and then either add to it, or discount from it ... for variable factors' ${ }^{128}$ The two dominant factors in the case were the estrangement and Heather's straitened circumstances, and Lord Hughes even suggested that it would have been legitimate for the judge to have concluded that it was entirely reasonable for no provision to be made at all in the will because of the estrangement (a matter on which leave to appeal had of course been refused by the Supreme Court in 2011). The judge was therefore definitely able to say that 'what reasonable provision would be was coloured by the nature of the relationship between mother and daughter'. ${ }^{129}$ The Court of Appeal's order, by contrast, had given 'little if any weight' to the length of the estrangement between the protagonists. ${ }^{130}$

The Supreme Court was also concerned that again 'little if any weight' had been given by the Court of Appeal's order to Melita's very clear wishes. ${ }^{131}$ It was incorrect to say that the charities' lack of any expectation of benefit was on a par with Heather's lack of any similar expectation. They were the beneficiaries under Melita's will, and were not required to justify their claim to the estate with reference to needs in the same way that Heather did. The Court of Appeal had erred in suggesting that they were not prejudiced by a higher award to Heather because they could not plead human needs, which is significant in light of their concession at trial that their needs and resources were irrelevant. Clearly the benefit to an estate beneficiary is inherently reduced by an order under the 1975 Act. The Supreme Court was sympathetic to the general position of charities in this context, emphasising that they 'depend heavily on testamentary bequests for their work, which is by definition of public benefit and in many cases will be for demonstrably humanitarian purposes'. ${ }^{132}$ One study indeed suggests that over 25 per cent of charitable donations come from wills. ${ }^{133}$ The Supreme Court also considered it erroneous to suggest that the court had no need to give specific consideration to Melita's wishes because Parliament had limited claims under the 1975 Act to particular circumstances. Those wishes were relevant factors and fell to be considered alongside the others.

On the second alleged error, that Judge Million had been unaware of the effect of his order on Heather's entitlement to benefits, the Supreme Court held that Judge Million had in fact addressed the impact on benefits. Lord Hughes regarded the essence of the Court of Appeal's criticism to be that the judge's order would have little or no value to Heather because of the impact on her benefits. He, however, held that if Heather spent the $£ 50,000$ in a particular way, that impact would be minimised. In fact, Lord Hughes suggested that the Court of Appeal had somewhat ironically given insufficient attention to the impact of its own order on Heather's benefits position. That said, Lady Hale was prepared to accept that the Court of Appeal's order was 'benefits-efficient' from both Heather and the public's point of view. ${ }^{134}$

The conclusion that Judge Million had made neither alleged error was sufficient to dispose of the case: the $£ 50,000$ award met many of Heather's needs for maintenance,

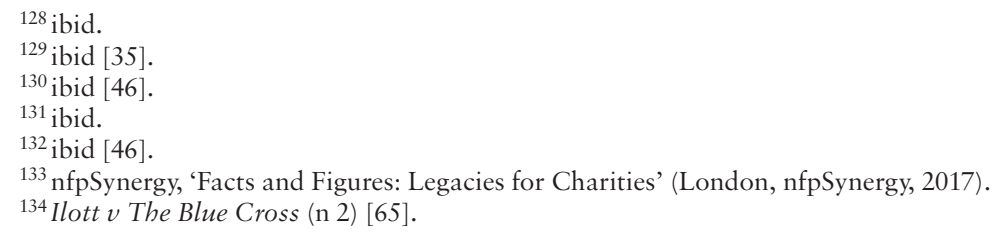


allowing her to 'buy much needed household goods and have a family holiday', ${ }^{135}$ and should be restored. These suggested uses for the money may not obviously be consistent with Judge Million's calculations, which were based on a comprehensive (albeit basic) standard of living. On Lord Hughes's analysis, however, it was 'a central feature of Mrs Ilott's financial position that although the family could manage - just - on its income, this was at the cost of being unable to maintain the ordinary domestic equipment on which every household depends'. ${ }^{136}$ He also held that, although Judge Million had taken into account what the government regarded as a minimum level of income, 'he did not make his award on this basis', ${ }^{137}$ and produced an approximated award reflecting the fact that Heather's needs exceeded driving lessons and a small amount of capital.

Even if housing provision had been appropriate, Lord Hughes held that a life interest would have been preferable to capital, even though the parties had agreed at trial that any award should take the form of capitalised maintenance. While there is no reason why housing cannot be maintenance in some cases, Lord Hughes emphasised that the overall power is to provide for maintenance and that housing is more likely to be provided by way of a life interest rather than a capital sum.

Lord Hughes appeared to approve the relevance of care to 1975 Act cases. He considered a hypothetical contrasting case to Ilott involving a

claimant [who was] a child of the deceased who had remained exceptionally and confidentially close to her mother throughout, had supported and nurtured her in her old age at some cost in time and money to herself, and ... had been promised many times that she would be looked after in the will.

While 'adhering to the concept of maintenance', he held that 'a judge ought in such circumstances to attach importance to the closeness of the relationship in arriving at his assessment of what reasonable financial provision requires'. ${ }^{138}$ That said, he was also anxious that 'care must be taken to avoid making awards under the 1975 Act primarily rewards for good behaviour on the part of the claimant or penalties for bad on the part of the deceased'. 139

\section{B. Lady Hale's Powerful Supplement}

Lady Hale then gave a striking supplementary judgment, with which Lords Wilson and Kerr agreed. As has been seen, she observed that Ilott raised 'some profound questions about the nature of family obligations, the relationship between family obligations and the state, and the relationship between the freedom of property owners to dispose of their property as they see fit and their duty to fulfil their family obligations', claiming that 'none [of those questions are] answered by the legislation which [the Supreme Court] had to apply'. ${ }^{140}$ It may be true that the questions are not conclusively resolved

\footnotetext{
135 ibid [66] (Lady Hale).

136 ibid [40].

137 ibid [43].

138 ibid [35].

${ }^{139}$ ibid [47].

140 ibid [49].
} 
on the face of the 1975 Act, but the Supreme Court did manage to resolve the case. In any event, Lady Hale criticised 'the unsatisfactory state of the present law' for 'giving ... no guidance as to the factors to be taken into account in deciding whether an adult child is deserving or undeserving of reasonable maintenance', particularly in light of the range of public views on the point. ${ }^{141}$ She took the unusual step of expressing 'regret that the Law Commission did not reconsider the fundamental principles underlying such claims when last they dealt with this topic in 2011'. ${ }^{142}$ It is somewhat ironic that, with her family law background, Lady Hale is entirely accustomed to applying, and, indeed, giving authoritative guidance on, ${ }^{143}$ section 25 of the Matrimonial Causes Act 1973, whose only remotely clear 'answer' is that the welfare of minor children of the family should be given first consideration in relief on divorce. ${ }^{144}$ It is clear from her judgment, however, that she regarded the question of maintaining spouses and that of maintaining children as significantly different.

\section{Implications}

The end result will be a relief for the charities, who took a financial and reputational risk in fighting the case all the way to the Supreme Court, which gave judgment well over 12 years after Melita's death. The charities did so largely on principle because of the possible wide impact of the Court of Appeal's approach. The decision will also be welcomed by many private client practitioners and those who support the idea that property rights extend to control on death and that able-bodied adult children should not be able to disrupt testamentary intentions.

Some of the clearly contestable elements of the Court of Appeal's judgment, such as the suggestion that the charities were not prejudiced by a higher award to Heather, have been satisfactorily resolved. But the Supreme Court's decision may itself be questioned in some respects. There would arguably be little point in the 1975 Act's application to non-spouse/civil partnership cases if it were not able to raise a claimant's standard of living reasonably significantly beyond what is available from state benefits. Otherwise, the Act would simply become a means for the state to save money rather than genuinely assisting those expressly listed as potential applicants, the money-saving potential of the Family Protection Act 1955 having been expressly recognised by the legislature in New Zealand. ${ }^{145}$ On the basis that the English Act is aimed at improving living standards beyond benefits, Heather had a need for maintenance by the standards of many people, and since the courts are often reluctant to consider the conduct regarding the relationships of the protagonists in intra-family disputes, as Lord Hughes recognised, it could

\footnotetext{
141 ibid [66].

$142 \mathrm{ibid}$.

${ }^{143}$ See, in particular, Miller v Miller; McFarlane v McFarlane [2006] UKHL 24, [2006] 2 AC 618.

${ }^{144}$ Matrimonial Causes Act 1973, s 25(1).

${ }^{145}$ Under the Social Security Act 2018, s 203, where an applicant for a benefit 'has a tenable claim under the Family Protection Act 1955 for a share of or provision out of the estate of a deceased relative' and 'has failed to take reasonable steps to advance that claim', the relevant body 'may refuse to grant the benefit, grant it at a reduced rate, or cancel a benefit already granted'. cf, eg, the more general (English) Housing Benefit Regulations SI 2006/213 r 49(2).
} 
be seen as surprising for the Supreme Court to accept that her claim should be quite so limited with reference to the relationship between mother and daughter. That said, if it is arguable that positive contributions and conduct should be given some recognition within the limitations of maintenance, ${ }^{146}$ a general idea that Lord Hughes appeared cautiously to approve, that is consistent with his reasoning on the converse case, where parent and child have not been close at all.

The debate over the proper balance between testamentary freedom and provision for family members will inevitably continue. For now, it seems as though the 'testamentary freedom' camp are in a stronger position than they were before the Supreme Court's decision. But it should be remembered that Heather Ilott still went away with something despite being left out of her mother's will (even if similar future claimants may not be so lucky and the details of an arrangement between her and the charities are not public), and it will be interesting to see whether Lady Hale's plea for reform is heeded.

\section{Academic Reaction}

On Douglas's analysis, the Supreme Court's decision 'will surely give pause to those who might be planning a challenge to wills of this kind; one may expect them now to face a harder task in satisfying the court that the deceased's wishes should be overridden'. ${ }^{147}$ Conway describes the case as one where 'the right outcome ... [was] more or less reached on the facts', but asserts that 'important issues remain'. ${ }^{148}$ In her view, '[ $\mathrm{f}$ ] or all the attention it attracted, Ilott was an atypical case, [such] that few other applications will replicate this particular scenario'. ${ }^{149}$ She finds it 'hard to disagree with the Supreme Court's assessment of the judgment below and the reasons for overturning it', since both estrangement and benefits were part of the factual matrix that the District Judge supportably took into account. ${ }^{150}$

Conway regards the Supreme Court's extensive analysis of the 1975 Act as 'the more pertinent aspects of the judgment ... likely to influence future claims under the Act'. ${ }^{151}$ On her analysis, while 'the Court of Appeal judgments ... were seen as turning points, signifying that adult children who had been disinherited (whether wholly or partly) could succeed and be given a significant award, despite not having been financially reliant on their dead parent', 'the Supreme Court ruling suggests otherwise, and that independent adult children who lack "reasonable financial provision" will probably receive much less generous awards than the Court of Appeal gave Heather Ilott'. ${ }^{152}$ In doing so, she considers that the Supreme Court 'probably return[ed] the law to its pre-Ilott position'. ${ }^{153}$

\footnotetext{
${ }^{146}$ See, eg B Sloan, Informal Carers and Private Law (Oxford, Hart Publishing, 2013) ch 5.

${ }^{147}$ G Douglas, 'Inheritance: Provision for Family and Dependants' [2017] Family Law 494, 496.

${ }^{148}$ H Conway, 'Rights versus Responsibilities: Adult Children, Parental Wealth and Contested Wills' (2017) 39 Journal of Social Welfare and Family Law 494, 494.

${ }^{149} \mathrm{H}$ Conway, 'Testamentary Freedom, Family Obligation and the Ilott Legacy' [2017] Conveyancer and Property Lawyer 372, 377.

${ }^{150}$ ibid 375

151 ibid.

${ }^{152}$ Conway (n 148) 496.

${ }^{153}$ Conway (n 149) 378.
} 
It 'reassures will-makers that, while their wishes may not always be respected, they now have much more prominence in family provision claims'. ${ }^{154}$ Conversely, 'independent adult children who have been disinherited by their parents will take little comfort from the Supreme Court ruling, and lawyers advising them should downgrade the chances of success or caution about more modest awards'. ${ }^{155}$ As Probert puts it 'assessing what was said - and what was not said - reveals a very strong preference for individuals being able to exercise their economic power beyond the grave'. ${ }^{156}$ She opines, however, that 'the case offers little by way of specific guidance for future litigants, even where the facts are substantially similar', and (perhaps more surprisingly) that '[i]t also makes it very difficult even to identify the crucial factors in Ilott itself'. ${ }^{15}$

Despite broadly supporting the result, Conway admits that:

One might question whether, in an era of reduced public spending and ongoing welfare reforms, Melita Jackson should have been able to leave an estate worth almost half a million pounds to three animal welfare charities while her daughter and her family survived almost exclusively on benefits and a small sum of savings.

She does, however, also say that ' $r$ ] eplacing state provision with estate provision in cases such as these would be extremely controversial, raising complex issues of law and social policy', and it is unclear whether a debate on the matter will be had. ${ }^{158}$

\section{E. The Influence of Ilott on Subsequent Cases}

The Supreme Court's decision in Ilott has already been cited by the Court of Appeal in Lewis $v$ Warner, ${ }^{159}$ by the High Court in Re Wynford Hodge, ${ }^{160}$ Ball $v$ Ball, ${ }^{161}$ Banfield $v$ Campbell, ${ }^{162}$ Ubbi $v$ Ubbi ${ }^{163}$ and Wellesley $v$ Earl Cowley, ${ }^{164}$ by County Courts in Re Nahajec ${ }^{165}$ and Miles $v$ Miles, ${ }^{166}$ and by the Family Court in $M v M .{ }^{167}$ The last decision did not concern the 1975 Act at all: $M$ was an ancillary relief on a divorce case in which Ilott was cited to highlight the difference between an 'evaluative' and a 'discretionary' determination. ${ }^{168}$

Lewis $v$ Warner involved a claim by a former cohabitant who was wealthy but sought the ability via the 1975 Act to buy the property that he had shared with the deceased for full valuable consideration, arguing that he needed to remain there because of his

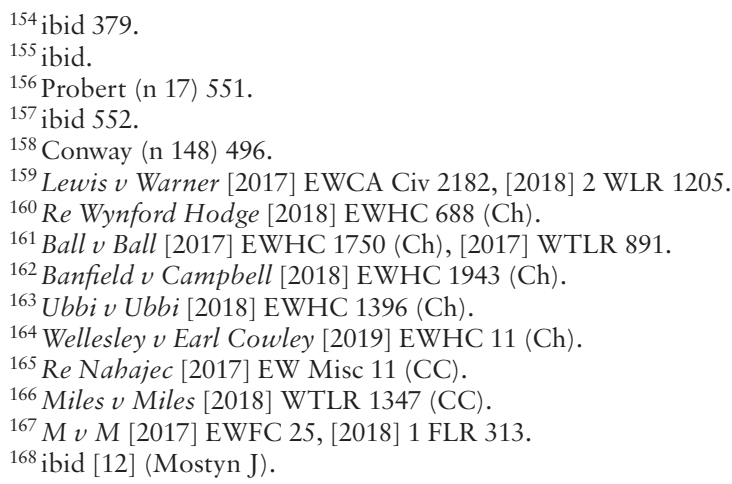


age and disability. Counsel for the deceased's daughter relied on Ilott to submit that the applicant 'had failed to advance a case that he needed any financial provision for his maintenance out of the deceased's estate (being significantly financially better off than the deceased, and able to afford alternative accommodation)' ${ }^{169}$ Significantly for present purposes, Sir Geoffrey Vos said that '[i]t is not actually necessary to look behind Ilott' in elucidating the relevant case law, 'because the relevant preceding cases are all referred to within Lord Hughes's seminal judgment'. ${ }^{170}$ Similarly, in Ball $v$ Ball it was said that Espinosa does not add anything to Ilott. ${ }^{171}$ In Lewis, lengthy passages were said to '[be] directly relevant to what this court has to decide' and 'provide the legal background without the need to trawl through the pre-existing authorities'. ${ }^{172}$ There were said to be 'clear indications' in Lord Hughes's judgment that 'the broad concept of "maintenance" ... can extend to the provision of a house in which the applicant can live, albeit that it might most often be provided by way of a life interest'. ${ }^{173}$ Mindful of Ilott's approach to needs, moral obligations and the appellate jurisdiction, the Court of Appeal upheld the first instance decision that the applicant should be allowed to purchase the property. Sir Geoffrey's remarks were themselves cited in Banfield $v$ Campbell in the course of granting the claimant a life interest in half the sale proceeds of his former partner's home for the purposes of providing alternative accommodation (with only a limited lump sum kept available in case adaptation was required). In Re Wynford Hodge it was said that Ilott 'emphasised that the statutory power is to provide maintenance, not to confer capital', ${ }^{174}$ albeit that on the facts of the case the care needs of the applicant made capital provision reasonable. In Re Nahajec the facts were said to be very similar to Ilott and extensive reference was made to it. ${ }^{175}$ In allowing the claim, the judge was adamant that he had done so not simply because Ilott had done so, but did note that 'in Ilott the claimant could meet her outgoings from her own resources but nevertheless it was considered that that did not disqualify her from an award'. ${ }^{176}$ The judge noted that he was awarding the claimant in Re Nahajec 11.3 per cent of the net estate, which was within 1 per cent of the 10.3 per cent awarded to Heather. ${ }^{177}$ In Ubbiv Ubbi, Master Shuman recognised Ilott's emphasis on testamentary freedom and the limitations of maintenance, but also that maintenance was not limited to subsistence in making provision for minor children born after their father's last will was made. Ball $v$ Ball, by contrast, is an example of a claim by estranged adult children failing following Ilott because the estate was small, the applicants' needs were not significantly different from those of the will beneficiaries and neither the deceased's conduct nor her husband's sexual abuse of the claimants created a moral obligation. Somewhat similarly, a $£ 20,000$ legacy was said to be reasonable in the context of 35-year estrangement despite a large estate and reliance on benefits in

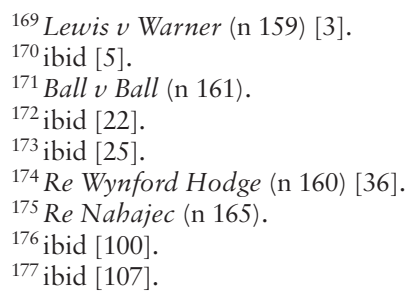


Wellesley $v$ Earl Cowley, with the judge adopting a single determination approach to the Act. In Miles $v$ Miles, moreover, Judge Farquhar invoked Ilott in holding that the District Judge below had given insufficient weight to the testator's wishes, and reduced the quantum for his separated widow.

Aside from case law per se, the Law Commission cited Ilott in discussing the relationship between mutual wills and the 1975 Act in its Consultation Paper on wills, noting that Lady Hale 'was critical of the lack of guidance provided in the statute as to how the court should deal with claims for financial provision'. ${ }^{178}$ Internationally, Ilott was widely cited in the South Australian Law Reform Institute's recent report on family provision. ${ }^{179}$

It is arguable that in none of these instances did Ilott make a fundamental difference to the matter under discussion. But it is plausible to argue that Ilott has become the 'go-to' authority under the 1975 Act (even in cases not involving children), and that its influence has already extended beyond that Act.

\section{CONCLUSION}

On what basis might Ilott be described as a 'landmark' case, particularly given the short time between the Supreme Court handing down its judgment and this chapter being written? The fact that it received quite so much judicial consideration over so many years is surely a key factor. There is also the fact that it was the first substantive consideration at the highest judicial level of the 1975 Act (more than 40 years after its enactment), and it may remain the only such example for some time. This is surely significant, even if Ilott's importance might have been greater still had the Supreme Court granted the charities permission to appeal the threshold stage in 2011.

More substantively, Ilott may not have broken entirely new ground, but it does confirm some vitally important principles both in respect of claims by adult children and under the 1975 Act generally. Conway has argued explicitly that ' $[t]$ he Supreme Court ruling in Ilott is not a landmark one in the sense of fundamentally altering the law on family provision', but that 'it is an important one in terms of analysing the 1975 Act and its operation, and emphasising some core principles'. ${ }^{180}$ These include: that 'maintenance' can be provided even where it is literally possible for an applicant to live without it, and that it can improve an applicant's situation beyond what is available from state benefits (even if the latter issue is crying out for further clarification); that a moral obligation or claim is not a required feature of a claim by an adult child; that testamentary freedom is an important value that should be given specific consideration by a judge deciding a 1975 Act claim; that non-human entities are not to be prejudiced by the Act merely because they do not have needs that are comparable to those of humans; that care on the one hand and estrangement on the other are both relevant but not decisive; that the absence of any

\footnotetext{
${ }^{178}$ Law Commission, Making A Will (Law Com 231, 2017) [12.42] fn 54.

${ }^{179}$ South Australian Law Reform Institute, "Distinguishing between the Deserving and the Undeserving": Family Provision Laws in South Australia' (Report 9 Adelaide, South Australian Law Reform Institute, 2017).

${ }^{180}$ Conway (n 149) 379.
} 
expectation of provision is not necessarily fatal; and that a life interest is generally to be preferred to capital housing provision under the Act.

Moreover, if the true test is that people keep on talking about Ilott, ${ }^{181}$ the level of media coverage and the likely impact of Ilott on relevant textbook chapters ${ }^{182}$ might be sufficient in themselves to qualify it as a 'landmark' case. There is also a possibility that Lady Hale's plea for reform will be heeded and that Ilott will herald the beginning of a new phase in the life of the 1975 Act. Whether or not this is a realistic prospect, it seems highly likely that Ilott will be cited and discussed for decades to come.

\footnotetext{
${ }^{181} \mathrm{~J}$ Snape and D de Cogan, 'Introduction: On the Significance of Revenue Cases' in J Snape and D de Cogan (eds), Landmark Cases in Revenue Law (Oxford, Hart Publishing, 2019) 10-15.

${ }^{182}$ See already A Learmonth et al, Williams, Mortimer \& Sunnucks - Executors, Administrators and Probate, 21st edn (London, Sweet \& Maxwell, 2018) pt 8.
} 